InVisible Culture • Issue 33: After Douglas Crimp

\title{
After Douglas Crimp \\ Questionnaire Response: T’ai Smith
}

\section{T'ai Smith}

Published on: Jan 05, 2022

DOI: $10.47761 / 494 a 02 f 6.7 e 451 a e 9$

License: Creative Commons Attribution 4.0 International License (CC-BY 4.0). 


\section{Motherly Lessons}

I attached a longer, unedited version of the following text to an email I sent to Douglas on December 12, 2018, while he was undergoing radiation treatment. He was not well, and I hoped it would convey the extent of my love and gratitude. I had many times expressed thanks to him as my doctoral supervisor, but I wanted him also to know how much he had shaped me as a person. On February 9, 2019, while in New York, I visited him at his apartment in Tribeca to chat and to bring him butter pecan ice cream; he lent me a bootleg copy of Warhol's Hedy for a project I was working on with a friend. This was the last time I saw him. At his memorial service in September 2019, someone mentioned to me that he read this text aloud at a dinner party with his friends around that time. I felt humbled and loved.

In grad school, Douglas Crimp was mother hen, always surrounded by a gaggle of chicks, whom he adored and who adored him. I took my first seminars with him in the fall of 1999, several months before I turned twenty-five, at a time when I was ignorant of the world, yet convinced I was right about most things. He was the perfect doctoral mother (note: he was never a father). Even when he used his editorial authority to suggest that the textual voice I had adopted for an seminar paper was "too snarky" (that I should be more generous with my audience), or that I had misused an idiomatic expression, his reproach was draped in care. Of course, this also meant I was acutely aware of his disappointments. He never told me, exactly, but I knew when I was somehow missing something, too beholden to a normative trope, or when I was too swayed by Marxist rhetoric. It was evident in that look he gave-bewildered and knowing. He never attempted to make me change, or even really expected me to change, but I took his lessons to heart. I held onto them, mulled over them, actively recalled them occasionally to remind myself of his methodological generosity and openness, and as a caution against being overly abstract or theoretical. The profound empathy I felt and sought to convey for the Bauhaus women-Otti Berger, Gunta Stölzl, and Anni Albers-came out of learning, from Douglas, how to express care in writing.

Re-reading Douglas's texts in recent years, I have picked up on the couple references to mothers, who emerge like ghosts. In an early essay on photography, Grandmother appears as the voice of authority on lace. In Our Kind of Movie, Mother provides love in the form of an Adrian dress, shipped to him without questioning his impulsive, 20something request. Douglas understood their sharing of textile techniques and clothes to be a reminder-not to dismiss or forget other arts, other ways of knowing.... I 
realize now the extent to which I learned how to be a mother from Douglas: the simultaneous care, empathy, and subtle way to transmit disappointment and love through the gaze. Disappointment can't help but be mixed up with love-in the recognition that the other is the not-self. Countering and emerging out of disappointment is the feeling of wonder and joy in actually seeing someone else learn to eat or dress or write on their own.

Methodological, or motherly, lessons.

In grad school, most uses of psychoanalysis in art historical writing seemed barbaric to me. Writing about "women" and weaving made me allergic to certain strains that were -ironically, I thought-tied to some positivistic determination of the self (the ego). I just don't feel myself to be a "woman," and couldn't imagine the people I wrote about did either. It hits me once in a while-like in arguments about housekeeping, or Heidegger - that I'm seen this way, and have, for a moment and over time, become it. For those who have been given but despise this title of "woman," gender is not just performative; it's a vicious cycle. Or a house of mirrors in which it is never clear who or what is being reflected or doing the reflecting. In Douglas's writings, however, psychoanalysis performs differently. He gently cajoles his reader to look at the bundle of contradictions that we are, and to feel a bit less judgmental. Whenever I think of Lacan's mirror stage essay, I think of Douglas-a narrative he relayed so eloquently during a seminar in 1999 that I still tell it to my classes as though I'm ventriloquizing him. In re-reading his writing, I understand that both self-recognition and misrecognition constitute my "self" fundamentally, and this is not a bad thing.

T'ai Smith is an associate professor of art history at The University of British Columbia, a mother, and a former VCS PhD student, who wrote her dissertation on the Bauhaus Weaving Workshop under the supervision of Douglas Crimp.

Click here to return to the other questionnaire responses. 